\title{
Drivers of going concern audit opinions: empirical evidence from Indonesia
}

\author{
Lina Rahmawati, SUROTO, \\ Faculty of Economics, Islamic University of Indonesia, \\ Condong Catur Depok, Sleman, Yogyakarta, Indonesia, 55283. \\ linarahmawatis06@gmail.com \\ Hadri, KUSUMA, \\ Faculty of Economics, Islamic University of Indonesia, \\ Condong Catur Depok, Sleman, Yogyakarta, Indonesia, 55283 \\ 883120104@uii.ac.id
}

\begin{abstract}
The study of the going concern audit opinions is an important component within the enhancement of firms' responsibility and stewardship. A going concern audit opinions implies that the independent auditor doubt the future of the firm. This study aimed to examine the drivers of the likelihood of the going-concern audit opinions. Previous studies revealed that there were inconsistent drivers influencing the going-concern audit opinion. This study shows similar results to prior works. The result indicates that firms' financial condition and profitability significantly affect the likelihood of the going-concern audit opinion, while firms' size and leverage are not the determinants of the intensity of the going concern audit opinion.
\end{abstract}

Keywords: Going Concern Audit Opinion, Financial Condition, Leverage, Profitability, Firm Size JEL Classification: M4, M1

\section{Introduction}

Financial statements are the form of the firms' management responsibility to their stakeholders. The statements contain information not only required by firms' owners, but also for the interested parties outside of the firms for decision-making. To avoid disputes among the parties, firms need the third and independent auditor to give whether firm's financial statements are fairly presented and there is no material misstatement in the statements. In addition, IAPI (2011) states that the auditor is responsible for evaluating whether there is considerable suspicion of the entity's ability to maintain its viability within a reasonable period of time. Therefore, when the auditor is in doubt with the 
entity's ability to maintain business continuity in the following period, the auditor is entitled to issue a going-concern audit opinion.

A going concern audit opinions is the opinion given by the auditor to the client, because the auditors' suspicion about the entity's ability to maintain its survival (IAPI, 2011). Indonesian Institutes of Certified Public Accountant states that the auditors' responsibility is to obtain sufficient and appropriate audit evidence regarding the accuracy of the use of business continuity assumptions by firms' management in the preparation and presentation of the financial statements, and to conclude whether there is a material uncertainty about the entity's ability to sustain viability (IAPI, 2013).

Previous researches have shown factors that significantly affected the going-concern audit opinions. However, the previous researches have yielded consistent results. For example Arsianto and Rahardjo (2013) found that audit of tenure had a significant effect on the going concern audit opinions, while Rakatenda and Putra (2016) failed to support the influence this factor. Tjahjani and Novianti (2014), Irwansyah, Oktavianti, and Hardayanti (2015) and Rahim (2016) also show that firms' financial condition stated was a significant factor to the going concern audit opinions, while Wulandari (2014) stated this driver was not significant. Furthermore, the leverage factor in Aryantika and Rasmini's research (2015) was a significant to the going concern audit opinions, the leverage was not important according to Wulandari (2014) and Rakatenda and Putra (2016). Other factors of auditor competence, firms' size and audit quality factor have mixed results.

The inconsistent results of the previous researches encourages for further studies. Khaddafi (2015) also suggested for further research by adding independent variables that could theoretically affect the going-concern audit opinion. Therefore, this study aimed to examine determinants of the goingconcern audit opinion. The studied drivers were firms' size, financial condition, profitability, audit quality, and leverage. These variables was the integration of several variables that have not been consistently done by Arsianto and Rahardjo (2013), Hadori and Sudibyo (2014), Tjahjani and Novianti (2014), Wulandari (2014), Aryantika and Rasmini (2015), Irwansyah, Oktavianti, and Hardayanti (2015), Khaddafi (2015), and Rakatenda and Putra (2016).

The remainder of this paper is organized as follows: Section 2 describes and explains the literature review and hypothesis development. Section 3 presents the methodology of the study; its study sample, operational definition of the study variables, and study models. Section 4 reports the empirical results, and finally section 5 presents the conclusions and recommendation. 


\section{Hypothesis development}

\subsection{Firms' Financial condition and going concern audit opinions}

Firms' financial condition shows that firms are factual. Firms' financial statements often indicate that they are experiencing a financial deficit or surplus. Firms with the usual financial deficit may have going concern problems (Tjahjani and Novianti, 2014). Firms that posted losses from the previous period and without improvement in their performance and firms that do not earn revenue signify bad firms' financial condition. Firms like this will have a great chance of getting a going concern audit opinions.

Stakeholder theory states that stakeholders have equal rights in obtaining firms' information to understand firms' conditions. The management of the company them will serve and satistify these parties through firm performance reports. Good firms' management performance can be indicated by firms' financial condition. If firms' owners see that firms' financial condition is good, they assume that the firms' management (agent) had managed the investments by the owners to firms well. A good firms' financial condition also shows an indicator that going concern problems may not occur. In other words, firms that have good firms' financial condition, then they have high probability to continue their main activities in the later period. Good firms' financial condition will guaranty future activities of the firm and therefore reduce the existence of the going-concern audit opinion.

The results of research by conducted by Tjahjani and Novianti (2014) and Irwansyah, Oktavianti, and Hardayanti (2015) show that firms' financial condition had a negative effect on the going-concern audit opinion. Firms that have good firms' financial condition had a small chance of receiving a going-concern audit opinion. Firms' financial condition that had no losses and generated revenue is considered to maintain the continuity of firms' business for the subsequent period. However, the previous study conducted by Wulandari (2014) gave different results. She found that firms' financial condition failed to affect the going-concern audit opinion. In this study, researchers follow research conducted by Tjahjani and Novianti (2014) and Irwansyah, Oktavianti, and Hardayanti (2015). Therefore, this study formulated the first hypothesis as follows:

H1: Firms' financial condition has a negative effect on the likelihood of the going-concern audit opinions 


\subsection{Leverage and going concern audit opinions}

One source of firms' to finance its activities is a debt. Firms' ability to meet liabilities to creditors is measured through ratio of leverage. High values of the leverage indicate high uses of liabilities. indicate The higher the ratio of leverage of the firms is then the greater the auditors' suspicions of the firms' continuity (Benny and Dwirandra, 2016). High uses of the leverage can increase the occurance of bankrupcy costs. Therefore, higher debt of a firm and ineffective in managing capital, the continuity of firms may be questionable.

The pecking order theory states that if firms require external funding, they prefer to using debt instead of new issues of common stocks. However, profitable firms use less debt because not only they have low debt ratio targets, but also firms do not need external funds (Radjamin and Sudana, 2014). Inversley, firms with the amount of debt that exceeds total assets may cause them to suffer from capital deficiency, or a negative equity balance. This situation will lower the firms' owners' trust level to firm's management, in managing their investments that had been provided (Rakatenda and Putra, 2016). This situation also confuses the auditor about the firm continuity in the future. Therefore, the higher the ratio of leverage, the more likely the auditor will provide the going-concern audit opinion.

The results of previous research conducted by Aryantika and Rasmini (2015) found that the ratio of leverage affected the going concern audit opinion. The results show that firms with high ratio of leverage had a high probability of getting auditors' going concern opinions. It was because the firm was considered to have financial problems, and unable to guarantee business continuity in the further period. Inverseley, the results of the previous researches conducted by Wulandari (2014), and Rakatenda and Putra (2016) indicated that the leverage had no effect on the going concern audit opinion. In this study the researchers follow the study of Aryantika and Rasmini (2015). Based on the above description, then the hyphothesis of this study is formulated as follows:

$\mathrm{H} 2$ : Leverage has a positive effect on the likelihood of the going-concern audit opinions.

\subsection{Profitability and going concern audit opinions}

Profitibility indicates the ability of a firm to yield incomes for its creditors and investors. Firms are deemed capable of fulfilling liability obligations and ensuring business continuity in the future. With high profits, firms can also fulfill their obligations to investors. Investors see the rate of return made by firms on investment activities Hadori and Sudibyo (2014). The higher the profit generated, the firms will increase investor confidence to keep investing in firms. Therefore, 
firms that can generate profits or profitable firms will have a small chance of getting a going concern audit opinion.

According to the stakeholder theory, firms operate not only fulfill the interests of firms, but also must provide benefits to all stakeholders. Therefore, the management of the firms should work hard and produce high incomes. High profit firms are expected to give high returns to firms' owner, so firms' owner feel satisfied and enhance their investment. The trust owned by firms' owner can also invite other investors to invest in the firms. In addition, firms are assumed to maintain their business continuity, since the profit earned can finance firms' operations in the next period. Therefore, the higher the firms' profit, the lower the likelihood that the auditor will provide a Firms that can generate profits or profitable firms will have a small chance of getting a going-concern audit opinion.

The results of the previous researches conducted by Aryantika and Rasmini (2015), Hadori and Sudibyo (2014), and Wulandari (2014), show that profitability had no effect on the Firms that can generate profits or profitable firms will have a small chance of getting a going concern audit opinion. The results of these studies indicate that firms that generate high profits were considered would lessened the provision of Firms that can generate profits or profitable firms will have a small chance of getting a going concern audit opinion. Profitable firms did not guarantee the survival of firms in further periods. The earned profit may be used for other financing purposes instead of investing on the main activities of the firms. Based on the above description, then this study hypothizes as follows:

H3: Profitability has a negative effect on the likelihood of the goingconcern audit opinions

\subsection{Firms' size and going concern audit opinions}

Firm size is an indicator showing a condition or character of a firm scale to classify a small up to big firm with indicators of total asset, logaritm of firm value, number of employees and soon. The common method to scale of firm is total asset since the amount of assets indicate the amount of money invested by stockholders and creditors. High values of firm asset indicate high amount of investments managed by the management of the company. As long as the managemnt utilizes these investment and yields high incomes, the firm has a good prospect in the future. Inversely, a poor performance from investing encourages the likelihood of uncertainty survival of the company. The management, however, will manage the amount of money invested to satistify 
its constituences. Therefore, the higher firms' size is, the less likely to receive a going concern audit opinion (Arsianto and Rahardjo, 2013).

The stakeholder theory suggests that the contituences can influence firms' management in managing potential firms. Firms with a large size will have high amount of investments and firms' owners will recruit competent firms' management to manage their money. According to Ballesta and Garcia (2005) and Junaidi and Hartono (2010) large firms should have better firms' management in managing firms, and are capable of producing quality financial statements when compared to small firms. Competent firms' management will be able to maintain and develop the investment owned. They can also optimize the use of size effectively and efficiently and to maintain the stability of operations or production firms for further periods. In this situation, auditors can be more confident about the future of the firms and may not give a going concern audit opinion.

In studies conducted by Arsianto and Rahardjo (2013), and Rakatenda and Putra (2016), firm size negatively affected the acceptance of a going concern audit opinion. The results of these studies proved that large firms had a little chance of receiving a going-concern audit opinion. Large firms with high size had the possibility to grow, thus avoiding the circumstances that make auditors provide a going-concern audit opinion. However, the studies conducted by Tjahjani and Novianti (2014), Wulandari (2014), and Irwansyah, Oktavianti, and Hardayanti (2015) found that firms' size had no effect on the going concern audit opinion. This study follows research conducted by Arsianto and Rahardjo (2013), and Rakatenda and Putra (2016). Based on the above description, then this study hypothizes as follows:

H4: Firms' Size negatively affects on the likelihood of the going concern audit opinions.

\section{Research methods}

The target of population in this study was manufacturing firms listed in Indonesia Stock Exchange (BEI). However, to include in the sample the firm must meet the critria of having completed financial statements, experiencing profits and having complted data to calculate the variables. These criteria resulted 165 firm-observtions. The data collection techniques employed was the documentation, a method of recording the data directly from the financial statements provided by Indonesian Stock Exchange (BEI). Table 1 shows the reference, source definition, and measurement variables extracted from finanacial statements used in this study. 
To examine the hypotheses, this study used a technique of the logistic regression equation because the dependent variable was dummy variable. Equation 1 represents the relationship among the variables.

OAGC $=\alpha+\beta 1 K K+\beta 2 L E V+\beta 3 R O A+\beta 4 S I Z E+\beta 5 O A T S+\varepsilon \ldots \ldots 1$ Legend:

$$
\begin{array}{ll}
\text { OAGC } & =\text { Going Concern Audit Opinions } \\
\text { KK } & =\text { Firms' Financial Condition } \\
\text { LEV } & =\text { Leverage } \\
\text { ROA } & =\text { Profitability } \\
\text { SIZE } & =\text { Firms' Size } \\
\text { OATS } & =\text { Previous Years Audit Opinion }
\end{array}
$$

\begin{tabular}{|c|c|c|}
\hline Variables & Reference & Indicator \\
\hline $\begin{array}{l}\text { Firms' Financial } \\
\text { Condition }\end{array}$ & Irwansyah, Oktavianti, and Hardayanti (2015) & $\begin{array}{l}\text { Revised Altman } \\
\text { Model }\end{array}$ \\
\hline Leverage & Wulandari (2014) & Debt to Equity Ratio \\
\hline Profitability & Wulandari (2014) & Return On Asset \\
\hline Firms' Size & & $\begin{array}{l}\text { Logarithm of } \\
\text { Revenue }\end{array}$ \\
\hline $\begin{array}{l}\text { Previous Years Audit } \\
\text { Opinion }\end{array}$ & Arsianto dan Rahardjo (2013) & Dummy Variables \\
\hline
\end{tabular}

Table 1. Variables and Measurements

\section{Results}

This section shows the descriptive data and the results of testing hypotheses. The descriptive data the descriptive data is to give an overview of the data in general, regarding the variables being studied. The data variables of current going audit opinion and previous years audit opinion were analyzed by using univariate analysis. The result of univariate analysis shows that the previous year audit opinion from manufacturing firms had non-going concern audit opinion with the amount of 123 firms or $74.5 \%$ while the firms that got going concern audit opinions were 42 firms or $25.5 \%$. This suggests that the majority of manufacturing firms from 2010 to 2014 had no suspicion as to the ability of the entity to maintain its viability. Current audit opinions show that firms had 124 nongoing-concern audit opinion or $75.2 \%$ while there were 41 firms having a going-concern audit opinion or $24.8 \%$. This suggests that the majority of manufacturing firms of 2011 to 2015 doubt the entity's ability to sustain survival. 
Table 2. Descriptive Data

\begin{tabular}{|l|c|c|c|c|}
\hline Statistic & $\begin{array}{c}\text { Financial } \\
\text { Condition }\end{array}$ & Leverage & Profitability & Firm Size \\
\hline Mean & -1.71715 & 1.620855 & -0.01041 & 5.703897 \\
\hline Maximum & 26.62000 & 70.83100 & 2.683000 & 8.020441 \\
\hline Minimum & -81.04 & -31.781 & -1.279 & 3.413467 \\
\hline Std. Dev. & 11.51548 & 9.447866 & 0.243293 & 0.799205 \\
\hline
\end{tabular}

The descriptive statistics of the maximum, minimum, mean, and standard deviation values describe the variables of firms' financial conditions, leverage, profitability and firms size are described using table 2 . Table 2 indicates that firms' financial condition had the lowest value of -81.040 and the highest value of 26.620. The variable of firms' financial condition had average value of -1.717 with the standard deviation of 11,515 . In the leverage variable, the minimum value obtained was -31.781 and the maximum value of 70.831 . In general, manufacture firms had a leverage of 1.621 and a standard deviation of 9.447. For the profitability variable, the minimum value obtained was -1.279 and the maximum value of 2.683. Generally, firms had negative profitability of -0.010 and standard deviation of 0.243 . In the Firms' Size variable, the minimum value obtained was 3.413 and the maximum value of 8.020 . The manufacturing firms had firms' size of 5.703 and standard deviation of 0.799 .

Table 3: Logistic Estimates and Standard Error

\begin{tabular}{|c|c|c|l|}
\hline Variables & $\begin{array}{c}\text { Coefficient } \\
\text { (standard error) }\end{array}$ & $\begin{array}{c}\text { Expected } \\
\text { sign }\end{array}$ & \multicolumn{1}{|c|}{ Hyphothesis } \\
\hline C & $\begin{array}{c}-1.353362 \\
(1.806994)\end{array}$ & + & \\
\hline KK & $\begin{array}{c}-0.133086 \\
(0.054666)^{* *}\end{array}$ & - & Supported \\
\hline LEV & $\begin{array}{c}-0.010208 \\
(0.024794)\end{array}$ & + & Not supported \\
\hline ROA & $\begin{array}{c}-3.680693^{* *} \\
(1.598796)\end{array}$ & - & Supported \\
\hline SIZE & $\begin{array}{c}-0.123160 \\
(0.312694)\end{array}$ & - & Not supported \\
\hline OATS & $\begin{array}{c}2.608919 \\
(0.443251)^{*}\end{array}$ & + & \\
\hline \multicolumn{2}{|c|}{ McFadden R-squared } & - & \\
\hline
\end{tabular}

* Significant at the $1 \%$ level and ${ }^{* *}$ significant at the $5 \%$ level 
To investigate the factors influencing the intensity of the going audit opinion we employed equation 1. Table 3 indicates the result of the test. Table 3 indicates that the result of weights showing the power of estimation between independent and dependent variables based on the substantive theory (Ghozali and Latan 2012). Table 3 also shows that prior year audit opinion as the controlling variable was significantly influencing the likelihood of the goingconcern audit opinion. Furthermore, McFadden R-squared was 0.7696 , implying that the intensity of the going concern audit opinion can be explained by firms' financial condition, leverage, profitability, firms' size as much as $76,96 \%$, while the rest was due to other influence of variables. This result calls for additional variables for furthes studies. Furthermore, table 3 shows the equation of the logistic regression.

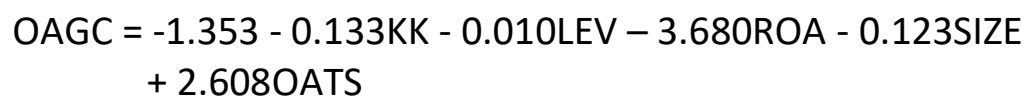

\section{Discussions, and Conclusions}

This section shows the results of testing hypotheses. In general, the data supported 2 hypotheses. First is the variable of firms' financial condition. This variable had value of -0.133 indicating that the variable lessened the likelihood of the going-concern audit opinions. This variable was also significant at the $5 \%$ level. Therefore, the first hypothesis stating that firms' financial condition has a negative effect on the likelihood of the going-concern audit opinions was support by the data.

This significant result can be interpreted that firms with good financial condition can guarantee business continuity, whereas firms with bad performance can be likely to get going concern audit opinions. According to stakeholder theory, all constituencies have equal rights to obtain firms information. This result indicates the management of the company them served and satisfied these parties through firms' performance or financial condition. Stakeholders viewed the condition of firms through financial statements that were the firms' management responsibility to firms' owners and creditors as its main stakeholders.

Furthermore, the strong negative relationship between firms' financial condition and going concern audit opinions support studies by Tjahjani and Novianti's research (2014), and Irwansyah, Oktavianti, and Hardayanti (2015). Inversely, the result of this hypothesis is different from that of Wulandari (2014) finding that firms' financial condition did not affect the going concern audit 
opinions. In other words, firms that are not experiencing financial distress, firms' business continuity will not be doubted by the auditor.

The second hypthotesis supported by the data is profitability. From table 3 , the variable of the profitability had an estimated value of -3.681 and significant at the $5 \%$ level. This result suggests that profitability of the firm lessened significantly the likelihood of the going-concern audit opinions. Following the stakeholder theory, firms with high incomes operate to provide benefits to constituences. The higher profit firms generate, firms were assumed to fulfill obligations to stakeholders. The higher profit firms also enhance them to finance new prospective activities and guarantee inside source of financing.

The significance of this second hypotheis is not in line with the previous researches conducted by Aryantika and Rasmini (2015), Hadori and Sudibyo (2014) and Wulandari (2014). They found that the profitability had no effect on the going concern audit opinions. This result, however, is in accordance with the hypothesis. Firms that have high profits are less likely that auditors give going concern audit opinions. The auditor considers that firms with high profits have capability to finance their operations in the following periods as well as to maintain business continuity in the following periods.

Table 3 also shows that the data failed to support 2 hypotheses. The variable of leverage did not significantly lower the intensity of the going-concern audit opinion. Table 5 shows the variable had an estimated value of -0.010 , implying a negative effect of leverage on the going concern audit opinions. However, it had a significance of 0.681 and was not significant at the $5 \%$. Therefore, the hypothesis stating that leverage had a positive effect on the going-concern audit opinions was failed to reject.

That there was no relationship between leverage and the going-concern audit opinions may follow the pecking order theory. According to this theory, firms tend to prefer internal source of financing such as firm profit to pay dividends and new investments. If the fund of companies was not enough internally, they will consider external sources as additional financing. The firms prefer debts to common stacks as external sources of financing because of cheaper floatation costs. Even though firms use many debts and therefore have high interest costs, they are able to cover firm's expenses including costs incurring from debt. This situation makes the independent auditor no doubt about the future of the firms. Therefore, firms with high uses of debts have no strong reasons obtained the going concern audit opinion.

The result of this hypothesis is not in line with Aryantika and Rasmini's research (2015) finding that the leverage had a positive effect on the going concern audit opinion. This study, however, supported studies by Wulandari (2014) and Rakatenda and Putra (2016) who found that there was no effect of 
the leverage on the going concern audit opinions. A possible explanation of this result may be that the firms managed their asset efficiently and experienced sales growth every year Wulandari (2014). These efficiency and sales increase can help firms to finance their activities internally.

The second unsupported hypothesis is firm size. Table 3 shows that the variable of firm size leverage did not significantly lower the intensity of the going-concern audit opinion. The firm's size variable had an estimated value of 0.123, indicating that an inverse relationship between firms' size and the goingconcern audit opinions. The coefficient of the variables was not also significant at the $5 \%$ level. Therefore, the hypothesis stating a negative relationship between firms' size and the going-concern audit opinion failed to reject. This result may be interpreted that large firms may not guarantee their business continuity nor can small firms not guarantee their future business.

The insignificant result of the firm size variable is different from that of the research conducted by Arsianto and Rahardjo (2013) and Rakatenda and Putra (2016). According to them, firm size negatively affected the going-concern audit opinion. However, the result of this study support studies by Tjahjani and Novianti (2014), Wulandari (2014) and Irwansyah, Oktavianti, and Hardayanti (2015) finding there was no relationship between firm size and the going concern audit opinion. A possible explanation of this result is due to management capability of the firm to operate and run firm activities. The bigger firm size is the more complex and complicated firm activities. Therefore, the independent auditor will not doubt about the firm continuity in the future as long as it is followed by a good management.

In summary, the study of the going concern audit opinions is an important component within the enhancement of firms' efficiency and performance. Previous studies revealed that there were inconsistent drivers influencing the going-concern audit opinion. This study shows similar results to prior works. The result indicates that firms' financial condition and profitability significantly affect the likelihood of the going-concern audit opinion, while firms' size and leverage are not the determinants of the intensity of the going-concern audit opinion.

The intensity of the going-concern audit opinion can be explained by firms' financial condition, leverage, profitability, firms' size as much as $76.96 \%$. This result implies the next studies calls for additional variables. Non-financial variables such as audit tenure and the competence of auditors may theoretically affect the going-concern audit opinion. 


\section{References}

[1] Arsianto, Maydica Rossa, and Shiddiq Nur Rahardjo. 2013. "Faktor-Faktor Yang Mempengaruhi Penerimaan Opini Audit Going Concern." Diponegoro Journal Of Accounting 2 (3): 1-26.

[2] Aryantika, Ni Putu Putri, and Ni Ketut Rasmini. 2015. "Profitabilitas, Leverage, Prior Opinion Dan Kompetensi Auditor Pada Opini Audit Going Concern." E-Jurnal Akuntansi Universitas Udayana 2: 414-25.

[3] Ballesta, JPS, and Emma Garcia-Meca. 2005. "Audit qualifications and corporate governance in Spanish listed firms", Managerial Auditing Journal, 20 (7), 725-738.

[4] Benny, I Made Priyana, and A A N B Dwirandra. 2016. "Kemampuan Opini Audit Tahun Sebelumnya Memoderasi Pengaruh Profitabilitas, Leverage, Likuiditas Pada 'Opini Audit Going Concern.'" E-Jurnal Akuntansi Universitas Udayana, 835-61.

[5] Ghozali, Imam, and Hengky Latan. 2012. Partial Least Square 'Konsep, Teknik Dan Aplikasi" SmartPLS 2.0 M3. Semarang: Badan Penerbit Universitas Diponegoro.

[6] Hadori, Baqarina, and Bambang Sudibyo. 2014. "Analisis Pengaruh Kualitas Finansial Perusahaan, Kualitas Auditor Dan Kualitas Perekonomian Terhadap Opini Audit (Going Concern)." Jurnal Economia 10 (1).

[7] IAPI. 2011. Standar Profesional Akuntan Publik 31 Maret 2011. 1st ed. Jakarta: Salemba Empat.

[8] IAPI. 2013. "Standar Profesional Akuntan Publik." IAPI. Retrived from http://iapi.or.id/detail/63-Standar-Profesional-Akuntan-Publik.

[9] Irwansyah, Bramantika Oktavianti, and Syarifah Hardayanti. 2015. "Pengaruh Faktor Keuangan Dan Faktor Non Keuangan Terhadap Pengungkapan Opini Audit Going Concern." Simposium Nasional Akuntansi XVIII.

[10] Junaidi, and Jogiyanto Hartono. 2010. "Faktor Non Keuangan Pada Opini Going Concern." Simposium Nasional Akuntansi XIII.

[11] Khaddafi, Muammar. 2015. "Effect of Debt Default, Audit Quality and Acceptance of Audit Opinion Going Concern in Manufacturing Company in Indonesia Stock Exchange." International Journal of Academic Research in Accounting, Finance and Management Science 5 (1): 80-91. doi:10.6007/IJARAFMS/v5-i1/1461.

[12] Radjamin, Iryuvita Januarizka Putri, and I Made Sudana. 2014. "Penerapan Pecking Order Theory Kaitannya Dengan Pemilihan Struktur Modal Perusahaan Pada Sektor Manufaktur Di Negara Indonesia Dan Negara Australia." Jurnal Manajemen Bisnis Indonesia 1: 451-68.

[13] Rahim, Syamsuri. 2016. "Pengaruh Kondisi Keuangan Perusahaan, Kualitas Audit Dan Opinion Shopping Terhadap Penerimaan Opini Going Concern ( Studi Empiris Pada Perusahaan Manufaktur Yang Terdaftar Di BEI )." Jurnal IImiah Akuntansi Dan Bisnis 11 (2): 74-82.

[14] Rakatenda, Gusti Ngurah, and I Wayan Putra. 2016. "Opini Audit Going Concern Dan FaktorFaktor Yang Mempengaruhinya." E-Jurnal Akuntansi Universitas Udayana 16: 1347-75.

[15] Tjahjani, Fera, and Rysa Feryna Novianti. 2014. "Audit Going Concern Opinion, Influenced By Audit Quality, Leverage, Prior Audit Opinion, Growth and Size Of The Companies." The 7th NCFB and Doctoral Colloquium 2014, 31-46.

[16] Wulandari, Soliyah. 2014. "Analisis Faktor-Faktor Yang Mempengaruhi Auditor Dalam Memberikan Opini Audit Going Concern." E-Jurnal Akuntansi Universitas Udayana 3: 53158. 